\title{
Mechanism of the Action of the Various Metal Fluorides on the Formation Process of Magnesium Aluminate
}

\author{
By \\ Masafumi MIYAMOTO, Minoru HASHIBA, Yukio NURISHI and Taizo HIBINO \\ (Department of Industrial Chemistry, Faculty of Engineering, Gifu University)
}

\section{Introduction}

The reaction between magnesium oxide and aluminum oxide was studied by many authors ${ }^{1 \sim 6)}$ and it is known that the reaction proceeds by the diffusion mechanism proposed by Wagner ${ }^{\text {? }}$. Some authors examined the effect of additives on the reaction process $^{8 \sim 10)}$. Recently Shimada et al. reported on the effect of addition of various metal fluorides on the formation process of magnesium aluminate from magnesium oxide and aluminum oxide ${ }^{11 \sim 12}$. They observed that in the presence of fluoride aluminum oxide reacts with magnesium oxide satisfying with Jander's equation but at the initial stage of the reaction the chemical interaction controlls the reaction process and that the degree of acceleration by the additives at the initial stage of the reaction is related to the standard enthalpy change of the following chemical equation (1)

$$
\begin{aligned}
& 4 \mathrm{Al}_{2} \mathrm{O}_{3}+6 \mathrm{MF}=2 \mathrm{AlF}_{3}+3 \mathrm{M}_{2} \mathrm{Al}_{2} \mathrm{O}_{4} \\
& 4 \mathrm{Al}_{2} \mathrm{O}_{3}+3 \mathrm{M}^{\prime} \mathrm{F}_{2}=2 \mathrm{AlF}_{3}+3 \mathrm{M}^{\prime} \mathrm{Al}_{2} \mathrm{O}_{4}
\end{aligned}
$$$$
\text { .................................(1) }
$$

and concluded that the lower the value of $\Delta H^{\circ}$ for the equation (1), the lower the initiation temperature of the formation of magnesium aluminate. It is the purpose of this report to examine the effect of the additives of various fluorides on the formation process of magnesium aluminate and to discuss on the factors controlling the accelerating effect of the additives and on the relation between the factors and thermodynamic quantities.

\section{Experimental}

Reagents and Apparatus. Potassium, calcium, strontium, cobalt, nickel and zinc fluorides are of chemical reagent grade and the other reagents used in all experiments are of guaranteed reagent grade. Aluminum oxide is of $\alpha$-form. Apparatus for $x$-ray diffraction, differential thermal analysis and thermogravimetric analysis are of Toshiba ADG-301 type, Mitamura 100 DTA-H and Rigaku DTA-TGA Köon type respectively.

Preparation of Samples and Identification of Products.
Samples were prepared by dry milling of the mixture of the reactants weighed to be a fixed concentration for $80 \mathrm{~min}$. Attention was paid to the constant operation of the milling to prevent the change in the distribution of the particle size.

The samples were heated in a furnace with $\mathrm{SiC}$ heater at a constant temperature for $30 \mathrm{~min}$ in air and then cooled to the room temperature. The products were identified with ASTM cards from the $\mathrm{x}$-ray diffraction pattern. The relative intensity of the $x$-ray diffraction was used as a measure of the amount of the product. It was calculated by GrossMartin method $^{13)}$ with standard of titanium dioxide in anatase form.

3 Results and Discussion

The effect of alkali and alkaline earth fluorides on the formation of magnesium aluminate

Fluorides were added to the mixtures of aluminum oxide and magnesium carbonate* and the mixtures were heated at various temperatures. Fig. 1 shows the results of the X-ray diffraction of these samples. The accelerating effect of alkali metal

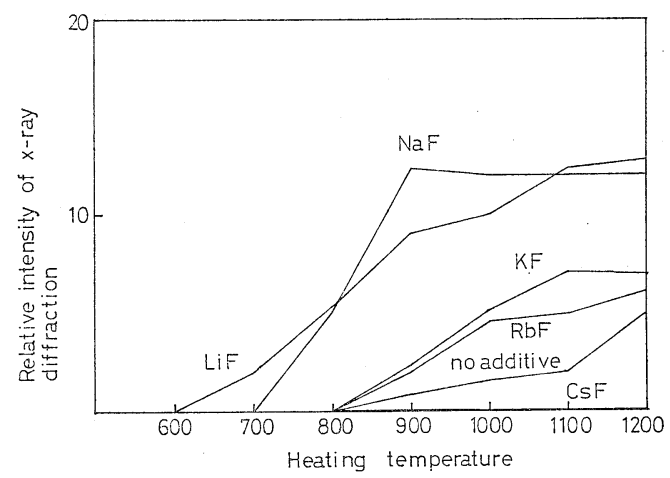

Fig. 1. The accelerating effect of alkali fluorides on the formation of magnesium aluminate. $\mathrm{MgCO}_{3}+\mathrm{Al}_{2} \mathrm{O}_{3}+\mathrm{MF} \longrightarrow$ heated for $30 \mathrm{~min}$ at $T^{\circ} \mathrm{C}$. $40 \quad 40 \quad 20 \mathrm{~mol} \%$

* The use of magnesium oxide in stead of magnesium carbonate gave no difference in the results. 


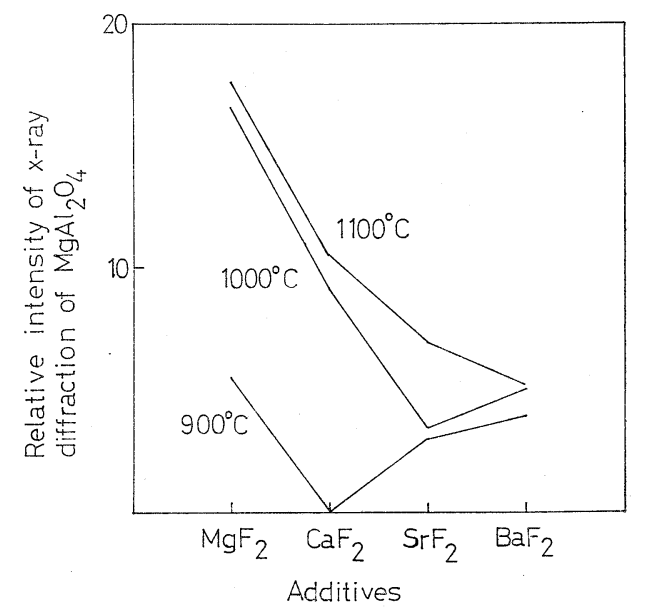

Fig. 2. The accelerating effect of alkali earth fluorides on the formation of magnesium aluminate

$\mathrm{MgCO}_{3}+\mathrm{Al}_{2} \mathrm{O}_{3}+\mathrm{MF}_{2} \longrightarrow$ heated for $30 \mathrm{~min}$ at $T^{\circ} \mathrm{C}$.

$40 \quad 40 \quad 20 \mathrm{~mol} \%$

Table 1. The enthalpy changes of the equation (1) for various metal fluorides ${ }^{19}$ )

\begin{tabular}{|c|c|c|c|c|c|c|}
\hline Fluorides & $\begin{array}{l}2 \Delta H^{\circ} \\
\left(\mathrm{AlF}_{3}\right)\end{array}$ & $\begin{array}{l}3 \Delta H^{\circ} \\
(\mathrm{MA}) *\end{array}$ & $\begin{array}{c}3 \Delta H^{\circ} \\
\left(\mathrm{M}_{2} \mathrm{O}\right)\end{array}$ & $\begin{array}{l}-\Delta H^{\circ} \\
\left(\mathrm{Al}_{2} \mathrm{O}_{8}\right)\end{array}$ & $\begin{array}{r}-64 H^{\circ} \\
(\mathrm{MF})\end{array}$ & $\begin{array}{l}\Delta H^{\circ} \\
(\mathrm{Ep} .(1))\end{array}$ \\
\hline $\mathrm{LiF}$ & -712.0 & -77.1 & -427.8 & 400.0 & 877.8 & 60.9 \\
\hline $\mathrm{NaF}$ & " & -125.4 & -302.1 & 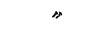 & 823.8 & 84.3 \\
\hline $\mathrm{KF}$ & " & & -259.2 & " & 807.0 & \\
\hline $\mathrm{Rb}$ & " & & -204.0 & " & 787.8 & \\
\hline $\mathrm{CsF}$ & " & & -227.7 & " & 761.4 & \\
\hline $\mathrm{BeF}_{2}$ & $"$ & -12.0 & -429.3 & $"$ & 729.0 & -24.3 \\
\hline $\mathrm{MgF}_{2}$ & " & -18.0 & -431.1 & " & 798.0 & 36.9 \\
\hline $\mathrm{CaF}_{2}$ & " & -11.1 & -454.8 & " & 876.0 & 98.1 \\
\hline $\mathrm{SrF}_{2}$ & " & -51.4 & -432.6 & " & 867.0 & 81.0 \\
\hline $\mathrm{BaF}_{2}$ & " & -72.0 & -417.0 & " & 863.1 & 62.1 \\
\hline $\mathrm{MnF}_{2}$ & $"$ & -31.5 & -276.0 & " & 570.0 & -49.5 \\
\hline $\mathrm{FeF}_{2}$ & " & 13.5 & -189.6 & $"$ & 504.0 & 15.9 \\
\hline $\mathrm{CoF}_{2}$ & " & -30.0 & -171.3 & " & 477.0 & -36.3 \\
\hline $\mathrm{NiF}_{2}$ & " & -27.0 & -172.5 & " & 474.0 & -37.5 \\
\hline $\mathrm{CuF}_{2}$ & $"$ & -32.1 & -111.3 & " & 384.0 & -71.4 \\
\hline $\mathrm{ZnF}_{2}$ & $"$ & -2.1 & -249.6 & " & 548.1 & -15.6 \\
\hline $\mathrm{CdF}_{2}$ & $"$ & 15.0 & -183.3 & $"$ & 502.2 & 21.9 \\
\hline
\end{tabular}

* $H^{\circ}$ (MA) shows the values of the enthalpy change of the formation of aluminate of the metal of the fluoride added from component oxides

fluorides on the formation of magnesium aluminate is the order of $\mathrm{LiF}>\mathrm{NaF}>\mathrm{KF}>\mathrm{RbF}>\mathrm{CsF}$. Addition of potassium fluoride or rubidium fluoride resulted little accelerating effect. The addition of cesium fluoride brought to the formation of an amorphous phase and the formation of magnesium aluminate could not be observed. Fig. 2 shows the results of the X-ray diffraction of the samples with alkaline earth fluorides heated at various temperatures. The accelerating effect at the temperature of $900^{\circ} \mathrm{C}$ is the order of $\mathrm{MgF}_{2}>\mathrm{CaF}_{2}<\mathrm{SrF}_{2}<\mathrm{BaF}_{2}$. The addition of calcium fluoride gave the least accelerating effect.

The values of $\Delta H^{\circ}$ for the equation (1) are collected in Table 1. For alkali metal fluorides the values are the order of $\mathrm{LiF}<\mathrm{NaF}<\mathrm{KF}$. The value for rubidium and cesium fluoride are not known. For alkaline earth metal fluorides these are the order of $\mathrm{MgF}_{2}<\mathrm{CaF}_{2}>\mathrm{SrF}_{2}>\mathrm{BaF}_{2}$. Therefore the claim by Shimada et al. ${ }^{12)}$ that the lower the values of $\Delta H^{\circ}$ for the equation (1), the lower the initiation temperature of the formation of magnesium aluminate seemed to be satisfied. However they also pointed out that the reaction (1) was accelerated in the presence of magnesium oxide and that the initiation temperature of the formation of magnesium aluminate is lowered by the incorporation of reaction (1) and (2)

$$
\begin{gathered}
4 \mathrm{Al}_{2} \mathrm{O}_{3}+6 \mathrm{MF}\left(3 \mathrm{M}^{\prime} \mathrm{F}_{2}\right)=2 \mathrm{AlF}_{3} \\
+3 \mathrm{M}_{2} \mathrm{Al}_{2} \mathrm{O}_{4}\left(3 \mathrm{M}^{\prime} \mathrm{Al}_{2} \mathrm{O}_{4}\right) \\
3 \mathrm{MgO}+2 \mathrm{AlF}_{3}=3 \mathrm{MgF}_{2}+\mathrm{Al}_{2} \mathrm{O}_{3} \ldots \ldots .
\end{gathered}
$$

But the relation between the incorporation of the reactions (1) and (2) and the formation of magnesium aluminate has not been analysed and the use of the $\Delta H^{\circ}$ of the reaction (1) in which the magnesium oxide does not participate as a measure of the degree of the acceleration has not sufficient basis.

Examination of the factor controlling the accelerating eflect.

The evidence that the accelerating effect caused by the simultaneous interaction of the fluoride with not only aluminum oxide but also magnesium oxide can be found in several instances. For instance sodium fluoride was added to the mixtures with various molar ratio of aluminum oxide to magnesium oxide and this mixtures were heated at a temperature. Fig. 3 shows the results of the X-ray diffraction of

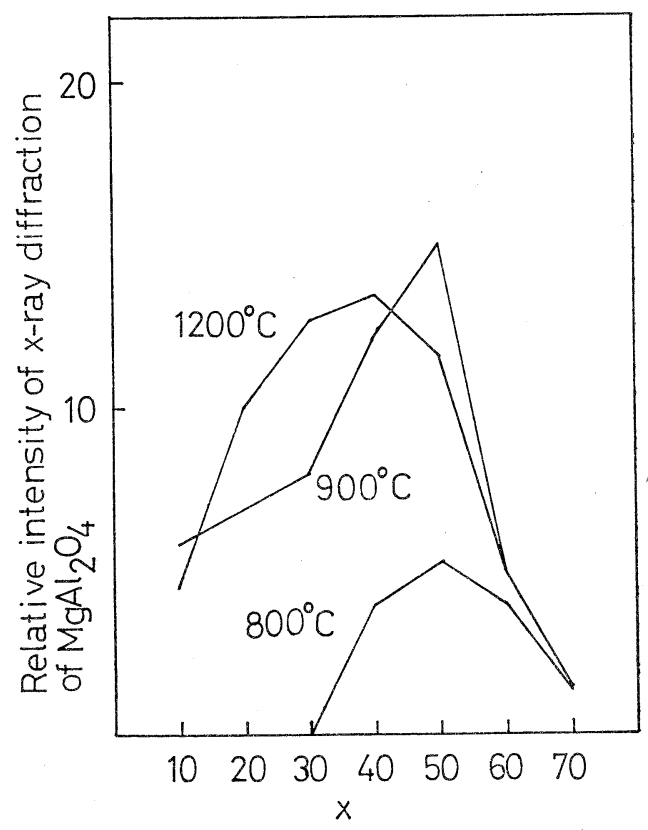

Fig. 3. Effect of composition of the samples on the formation of magnesium aluminate. $\mathrm{MgCO}_{3}+\mathrm{Al}_{2} \mathrm{O}_{3}+\mathrm{NaF} \longrightarrow$ heated for $30 \mathrm{~min}$ at $T^{\circ} \mathrm{C}$. $80-x \quad x \quad 20 \mathrm{~mol} \%$ 
the samples. The formation of magnesium aluminate was enhanced in the composition range of the excess amount of aluminum oxide at the initiation temperature of $800^{\circ} \mathrm{C}$ on the reaction process. On the other hand aluminum oxide and sodium fluoride without magnesium oxide were mixed and heated at various temperatures. The results of the X-ray diffraction, the differential thermal analysis and the thermogravimetric analysis of these samples are shown in Fig. 4. At the initiation temperature of $800^{\circ} \mathrm{C}$ of the formation of magnesium aluminate no chemical changes were observed in the two components system of aluminum oxide and sodium fluoride. The reaction was observed above the temperature of $1,000^{\circ} \mathrm{C}$. These facts support the assumption by Shimada et al. that the reaction between aluminum oxide and the fluoride is accelerated in the presence of magnesium oxide and it can be estimated that it is necessary for the three components

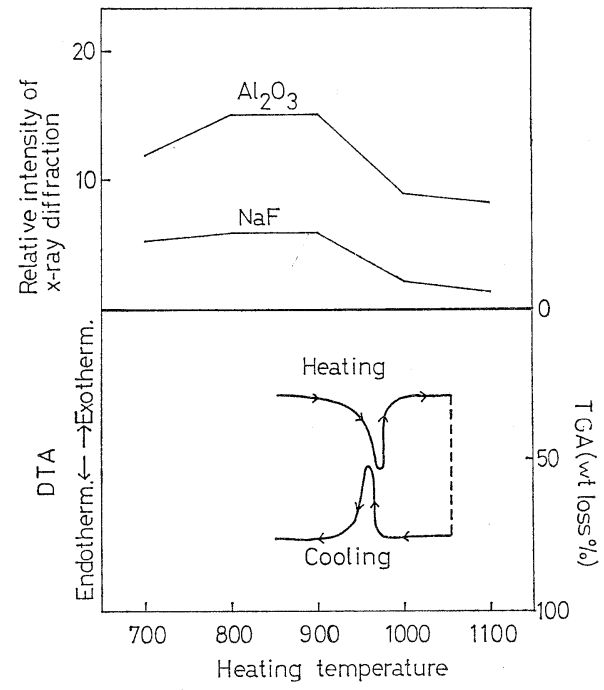

Fig. 4. The reaction between aluminum oxide and sodium fluoride.

$$
\mathrm{Al}_{2} \mathrm{O}_{3}+\mathrm{NaF}
$$

$$
80 \quad 20 \mathrm{~mol} \%
$$

of magnesium oxide, aluminum oxide and the fluoride to interact simultaneously with each other in the initial process of the formation of magnesium alumi nate. The authors have pointed out ${ }^{14 \sim 17)}$ that the effects of the additives on the formation process of various compounds are often initiated by the simultaneous interaction of the three components of two reactants and the fluoride. However this simultaneous interacting state has not been analysed enough. As described above it is not suitable to use the value of $\Delta H^{\circ}$ of the chemical equation (1) to analyse the mechanism of the acceleration of the additives because this chemical equation does not include magnesium oxide which is important to the accele- ration process including the interacting state of the three compo- nents. It is necessary for this purpose to find a thermodynamic quantity related to the simultaneous interacting state of the three components.

Consideration of the mechanism of the acceleration through the simultaneous interacting state of the three components and of the thermodynamic quantities related to this state

Two types of simultaneous interacting state of the three components of aluminum oxide, magnesium oxide and additives of metal fluorides $\mathrm{MF}\left(\mathrm{M}^{\prime} \mathrm{F}_{2}\right)$ may be possible. The one is the interaction named A type in which the metal ion of the additives attacks mainly to the aluminum oxide and on the other hand the fluoride ion interacts with magnesium oxide. The other is the interaction named B type in which the metal of the additives attacks mainly to the magnesium oxide and on the other hand the fluoride ion interacts with the aluminum oxide. But the enthalpy change of the chemical equation (2) gives a negative value. This shows that magnesium fluoride is more stable than aluminum fluoride in this reaction. Therefore the interaction of the A type is supposed to be much possible. So the mechanism of the formation of magnesium aluminate through the reactive simultaneous interacting state of the three components which is regarded as an activated state was supposed to be like a following reaction scheme in Fig. 5. Fig. 6 shows that sodium aluminate previously prepared by the reaction of sodium carbonate with aluminum oxide reacts with magnesium fluoride to form magnesium aluminate. This fact ${ }_{2}^{\mathbf{w}}$ supports the assumption of the reaction

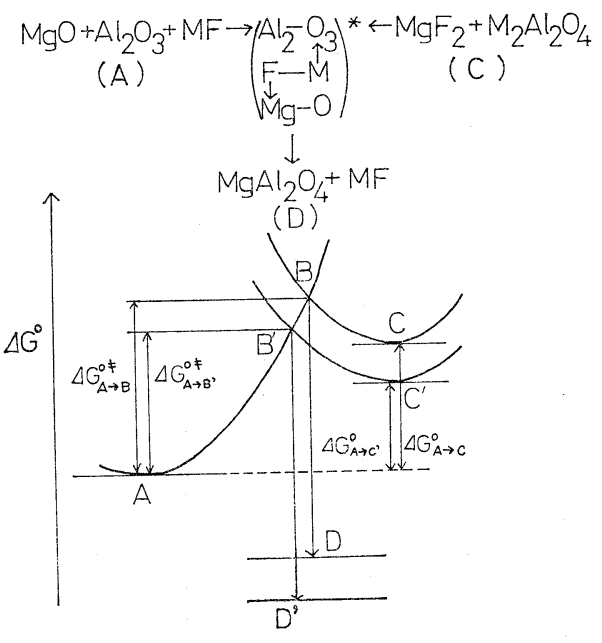

Fig. 5. Reaction scheme of the formation of magnesium aluminate through the active simultaneous interacting state of the three components. 


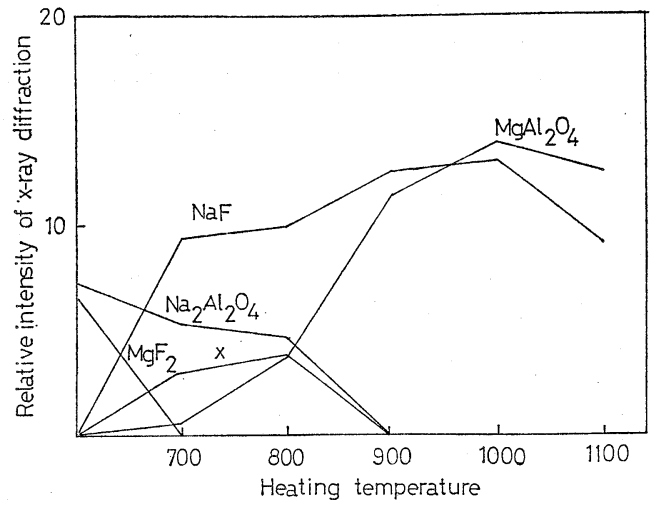

Fig. 6. Formation of magnesium aluminate from sodium aluminate and magne. sium fluoride.

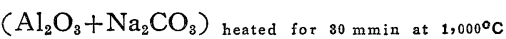
$33.3 \quad 33.3$

$+\mathrm{MgF}_{2} \longrightarrow$ heated for $30 \mathrm{~min}$ at $T^{\circ} \mathrm{C}$. $33.3 \mathrm{~mol} \%$

of the right hand side in the scheme. A conceptional figure of the relation to the changes of the free energy of the reacting system is also shown in Fig. 5. From these relationship the value of the $\Delta H^{\circ}$ for the following chemical reaction (4) can be used as a measure of the variation of the activation energy of the formation of magnesium aluminate based on the assumption of Linear Free Energy Relationship ${ }^{18)}$.

$$
\begin{aligned}
\mathrm{MgO} & +\mathrm{Al}_{2} \mathrm{O}_{3}+2 \mathrm{MF}\left(\mathrm{M}^{\prime} \mathrm{F}_{2}\right) \\
& =\mathrm{MgF}_{2}+\mathrm{M}_{2} \mathrm{Al}_{2} \mathrm{O}_{4}\left(\mathrm{M}^{\prime} \mathrm{Al}_{2} \mathrm{O}_{4}\right)
\end{aligned}
$$

The values of $\Delta H^{\circ}$ of the chemical equation (4) for various additives of alkali and alkaline earth fluorides are collected in Table 2. For alkali fluorides the value of $\Delta H^{\circ}$ changes in the order of $\mathrm{LiF}$

Table 2 The enthalpy changes of the equation

\begin{tabular}{|c|c|c|c|c|c|c|}
\hline Fluorides & $\begin{array}{l}\Delta H^{\circ} \\
(\mathrm{MA})^{*}\end{array}$ & $\begin{array}{l}\Delta H^{\circ} \\
\quad(\mathrm{MO})\end{array}$ & $\begin{array}{l}\Delta H^{\circ} \\
\left(\mathrm{MgF}_{2}\right)\end{array}$ & $\begin{array}{r}-\Delta H^{\circ} \\
\left(\mathrm{MF}_{2}\right)\end{array}$ & $\begin{array}{l}-\Delta H^{\circ} \\
(\mathrm{MgO})\end{array}$ & $\begin{array}{c}\Delta H \\
(\mathrm{Eq} \cdot(4))\end{array}$ \\
\hline $\mathrm{LiF}$ & -25.7 & -142.6 & -266.0 & 292.6 & 143.7 & 2.0 \\
\hline $\mathrm{NaF}$ & -41.8 & -100.7 & " & 274.6 & $"$ & 9.3 \\
\hline $\mathrm{KF}$ & & -86.4 & $"$ & 269.0 & $"$ & \\
\hline $\mathrm{RbF}$ & & -68.0 & $"$ & 262.6 & $"$ & \\
\hline $\mathrm{CsF}$ & & -75.9 & $"$ & 253.8 & $"$ & \\
\hline $\mathrm{BeF}_{2}$ & -4.0 & -143.1 & " & 243.0 & $"$ & -26.4 \\
\hline $\mathrm{MgF}_{2}$ & -6.0 & -143.7 & " & 266.0 & $"$ & -6.0 \\
\hline $\mathrm{CaF}_{2}$ & -3.7 & -151.6 & $"$ & 292.0 & $"$ & 14.4 \\
\hline $\mathrm{SrF}_{2}$ & -13.8 & -144.2 & $"$ & 289.0 & $"$ & 8.7 \\
\hline $\mathrm{BaF}_{2}$ & -24.0 & -139.0 & " & 287.7 & $"$ & 2.4 \\
\hline $\mathrm{MnF}_{2}$ & -10.0 & -92.0 & $"$ & 190.0 & " & -34.3 \\
\hline $\mathrm{FeF}_{2}$ & -10.7 & -63.2 & $"$ & 168.0 & $"$ & -28.2 \\
\hline $\mathrm{CoF}_{2}$ & -9.0 & -57.1 & $"$ & 159.0 & $"$ & -29.4 \\
\hline $\mathrm{NiF}_{2}$ & -0.7 & -57.5 & " & 158.0 & " & -22.5 \\
\hline $\mathrm{CuF}_{2}$ & 5.0 & -37.1 & $"$ & 128.0 & $"$ & -26.4 \\
\hline $\mathrm{ZnF}_{2}$ & -10.5 & -83.2 & " & 182.7 & $"$ & -33.3 \\
\hline $\mathrm{CdF}_{2}$ & 4.5 & -61.1 & $"$ & 164.7 & $"$ & -11.5 \\
\hline
\end{tabular}
(4) for various metal fluorides ${ }^{19}$

* $\Delta H^{\circ}(\mathrm{MA})$ shows the values of the enthalpy change of the formation of aluminate of the metal of the fluoride added from component oxides
$<\mathrm{NaF}<\mathrm{KF}$. For rubidium and cesium fluorides the value of $\Delta H^{\circ}$ are not known. However it can be seen that the additives which give a lower value of $\Delta H^{\circ}$ of the equation (4) is more effective for the acceleration of the formation of magnesium aluminate. The order of the magnitude of the $\Delta H^{\circ}$ of the reaction (4) for alkali metal fluorides, $\mathrm{LiF}<$ $\mathrm{NaF}<\mathrm{KF}<\mathrm{RbF}<\mathrm{CsF}$, is governed by the order of the standard enthalpy change of the formation of the alkali oxide, i.e. $\mathrm{Li}_{2} \mathrm{O}<\mathrm{Na}_{2} \mathrm{O}<\mathrm{K}_{2} \mathrm{O}<\mathrm{Rb}_{2} \mathrm{O}<\mathrm{Cs}_{2} \mathrm{O}$ (3.rd column in Table 2). This fact means that the tendency for the degree of the acceleration by the addition of alkali fluoride results from the difference of the action of alkali metal cation on the oxygen ion coming from the magnesium oxide. On the other hand for alkaline earth fluoride the degree of the acceleration of the formation of magnesium aluminate is in the order of $\mathrm{MgF}_{2}>\mathrm{CaF}_{2}<\mathrm{SrF}_{2}<$ $\mathrm{BaF}_{2}$. The changes of the values of $\Delta H^{\circ}$ are the order of $\mathrm{MgF}_{2}<\mathrm{CaF}_{2}>\mathrm{SrF}_{2}>\mathrm{BaF}_{2}$. Calcium fluoride gives the most high value. From comparison of these data the small $\Delta H^{\circ}$ also corresponds to the high degree of the acceleration for the addition of alkaline earth fluorides. This order of the $\Delta H^{\circ}$ of the reaction (4) for alkaline earth fluorides is governed by the order of the standard enthalpy changes of the formation of the alkaline earth fluoride (in the 5 th column of the Table 2 ) and of the formation of alkaline earth aluminate from the component oxides (in the second column of the Table 2). This means that the tendency for the degree of the acceleration with the addition of alkaline earth fluoride results first from the difference in the easiness for breaking the bond between alkaline earth metal ion and fluoride ion and second from the difference between the acidity of the aluminum oxide and the basicity of the alkaline earth oxides.

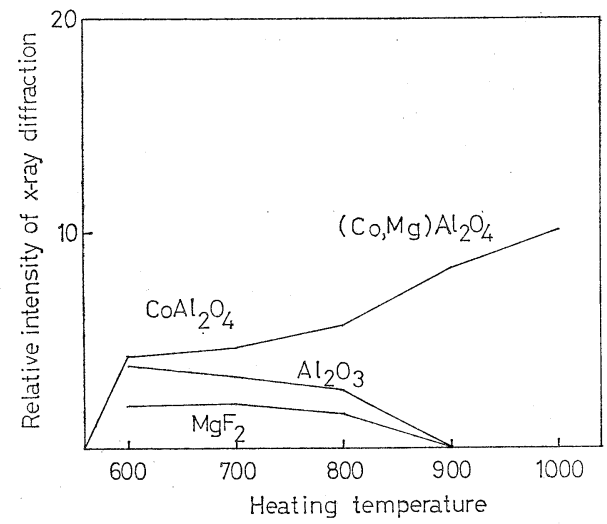

Fig. 7 Effect of the addition of cobalt fluoride on the reaction between aluminum oxide and magnesium carbonate.

$\mathrm{Al}_{2} \mathrm{O}_{3}+\mathrm{MgCO}_{3}+\mathrm{CoF}_{2} \longrightarrow$ heated for $30 \mathrm{~min}$ at $T^{\circ} \mathrm{C}$. $40 \quad 40 \quad 20 \mathrm{~mol} \%$ 


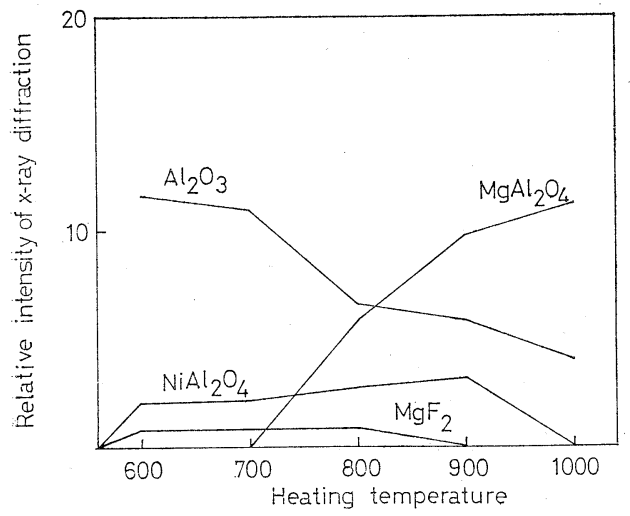

Fig. 8. Effect of the addition of nickel fluoride on the reaction between aluminum oxide and magnesium carbonate.

$\mathrm{Al}_{2} \mathrm{O}_{3}+\mathrm{MgCO}_{3}+\mathrm{NiF}_{2} \longrightarrow$ heated for $30 \mathrm{~min}$ at $T^{\circ} \mathrm{C}$. $40 \quad 40 \quad 20 \mathrm{~mol} \%$

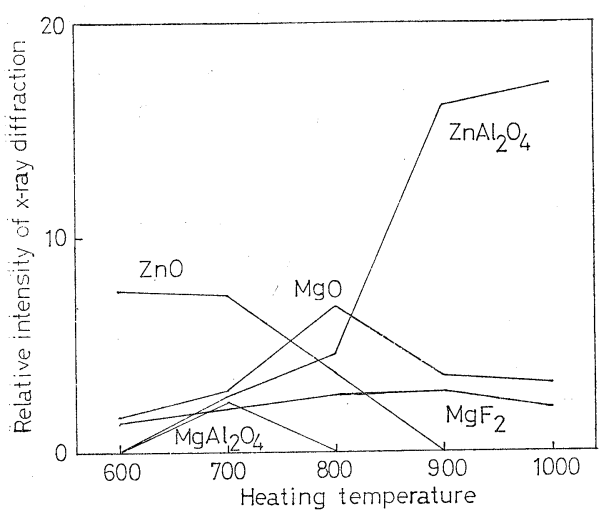

Fig. 9. Effect of the addition of zinc fluoride on the reaction between aluminum oxide and magnesium carbonate.

$\mathrm{Al}_{2} \mathrm{O}_{3}+\mathrm{MgCO}_{3}+\mathrm{ZnF} \longrightarrow$ heated for $30 \mathrm{~min}$ at $T^{\circ} \mathrm{C}$

$$
\mathrm{Al}_{40} \mathrm{O}_{3}+\mathrm{MgCO}_{8}+20 \mathrm{~mol} \%
$$

The effect of fluorides of the other divalent cations

The effects of the addition of each fluoride of cobalt, nickel and zinc were examined. Fig. 7, 8 and 9 show the results of the X-ray diffraction of these samples. Exchange reaction between the fluoride and magnesium oxide occurred easily to form magnesium fluoride. With this exchange reaction the formation of the aluminate of the cation of the added fluoride proceeded preferentially and was markedly accelerated in comparison with the formation from their component oxides in the absence of fluoride. The formation of magnesium aluminate was observed at the temperature of $800^{\circ} \mathrm{C}$. A little accelerating effects on the formation of magnesium aluminate were obtained.

The values of $\Delta H^{\circ}$ of the equation (4) for the fluorides were collected in Table (2). These negative value come from the large negative property of the enthalpy chages of the formation of magnesium fluoride. In the presence of magnesium fluoride the thermodynamic stability of the aluminate of the various cations to magnesium aluminate could be judged with the enthalpy change of the following equation (5)

$$
\begin{aligned}
& \mathrm{M}_{2} \mathrm{Al}_{2} \mathrm{O}_{4}+\mathrm{MgF}_{2}=\mathrm{MgAl}_{2} \mathrm{O}_{4}+2 \mathrm{MF} \\
& \mathrm{M}^{\prime} \mathrm{Al}_{2} \mathrm{O}_{4}+\mathrm{MgF}_{2}=\mathrm{MgAl}_{2} \mathrm{O}_{4}+\mathrm{M}^{\prime} \mathrm{F}_{2}
\end{aligned}
$$

The values of $\Delta H^{\circ}$ of the equation (5) are shown in Table 3. For the aluminates of alkali and alkaline earth metals the value of $\Delta H^{\circ}$ of the equation (5) shows negative properties. But for cobalt, nickel and zinc aluminates the values of $\Delta H^{\circ}$ of the equation (5) are positive. This shows that zinc, nickel and cobalt aluminates are stable in the presence of magnesium fuooride. This is attributed to the large negative amount of the enthalpy change of the formation of magnesium fluoride. Therefore it is

Table 3 The enthalpy changes of the equation

\begin{tabular}{|c|c|c|c|c|c|c|c|}
\hline Metals & $\begin{array}{l}\Delta H^{\circ} \\
\left(\mathrm{MgAl}_{2} \mathrm{O}_{4}\right)\end{array}$ & $\begin{array}{l}\Delta H^{\circ} \\
(\mathrm{MgO})\end{array}$ & $\begin{array}{l}\Delta H^{\circ} \\
(\mathrm{MF})\end{array}$ & $\begin{array}{l}-\Delta H^{\circ} \\
(\mathrm{MA})^{*}\end{array}$ & $\begin{array}{l}-\Delta H^{\circ} \\
\left(\mathrm{M}_{2} \mathrm{O}\right)\end{array}$ & $\begin{array}{l}-\Delta H H^{\circ} \\
\left(\mathrm{MgF}_{2}\right)\end{array}$ & $\begin{array}{l}\Delta H^{\circ} \\
(\mathrm{Eq} . \\
(5))\end{array}$ \\
\hline $\mathrm{Li}$ & -6.0 & -143.7 & -292.6 & $6 \quad 25.7$ & 142.6 & 266.0 & -8.0 \\
\hline $\mathrm{Na}$ & $"$ & " & -274.6 & 41.8 & 100.7 & " & -15.8 \\
\hline $\mathrm{K}$ & " & $"$ & -269.0 & & 86.4 & " & \\
\hline $\mathrm{Rb}$ & " & " & -262.6 & & 68.0 & $"$ & \\
\hline $\mathrm{Cs}$ & $"$ & $"$ & -253.8 & & 75.9 & $"$ & \\
\hline $\mathrm{Be}$ & " & $"$ & -243.0 & 4.0 & 143.1 & " & 20.4 \\
\hline $\mathrm{Mg}$ & " & " & -266.0 & 6.0 & 143.7 & $"$ & 0.0 \\
\hline $\mathrm{Ca}$ & $"$ & $"$ & -292.0 & 3.7 & 151.6 & " & -20.4 \\
\hline $\mathrm{Sr}$ & $"$ & " & -289.0 & 13.8 & 144.2 & " & -14.7 \\
\hline $\mathrm{Ba}$ & $"$ & $"$ & -287.7 & 724.0 & 139.0 & $"$ & -8.4 \\
\hline Mn & $"$ & $"$ & -190.0 & 10.0 & 92.0 & " & 28.3 \\
\hline $\mathrm{Fe}$ & $"$ & " & -168.0 & 10.7 & 63.2 & $"$ & 22.2 \\
\hline Co & $"$ & $"$ & -159.0 & 9.0 & 57.1 & $"$ & 23.4 \\
\hline $\mathrm{Ni}$ & " & $"$ & -158.0 & 0.7 & 57.5 & $"$ & 16.5 \\
\hline $\mathrm{Cu}$ & " & " & -128.0 & $0-5.0$ & 37.1 & $"$ & 20.4 \\
\hline $\mathrm{Zn}$ & $"$ & " & -182.7 & 10.5 & 83.2 & " & 27.3 \\
\hline $\mathrm{Cd}$ & " & $"$ & -164.7 & $7-4.5$ & 61.1 & " & 8.2 \\
\hline
\end{tabular}
(5) for various metal fluories and aluminates ${ }^{19}$ )

* $H^{\circ}(\mathrm{MA})$ shows the value of the enthalpy change of the formation of aluminate of the metal of the fluoride added from component oxides

necessary for the value of $\Delta H^{\circ}$ of the equation (5) to be negative to form magnesium aluminate in the presence of metal fluoride. This also means that it is necessary to use the more stable fluoride as an additive than magnesium fluoride for this purpose.

\section{Conclusion}

The effect of addition of various metal fluorides on the initial stage of the formation of magnesium aluminate from aluminum oxide and magnesium carbonate was studied and the following results were obtained.

The addition of alkali fluoride accelerated the formation of magnesium aluminate and the order of acceleration is of $\mathrm{LiF}>\mathrm{NaF}>\mathrm{KF}>\mathrm{RbF}>\mathrm{CsF}$. The 
addition of alkaline earth fluoride accelerates the reaction in the order of $\mathrm{MgF}_{2}>\mathrm{CaF}_{2}<\mathrm{SrF}_{2}<\mathrm{BaF}_{2}$. It was estimated that the additives accelerate the reaction through the active simultaneous interacting state of the three components of aluminum oxide, magnesium oxide and the additives. The reaction scheme of the formation of magnesium aluminate through this reactive simultaneous interacting state of the three components was proposed and on this reaction scheme it was shown that the enthalpy change of the equation (4) could be used as a measure of the degree of the acceleration of the additives on the formation of magnesium aluminate.

\section{Acknowledgement}

The authors thank to Dr. S. Shimada for his helpful discussions.

\section{References}

1) J. Hlavac, "Reactivity of Solids" Proceedings of the 4 th international symposium on the reactivity of solids, edited by J.H. De Boer, (Pub. 1961) Elsevier, p. 129.

2) G.F. Huttig, R. Reidlinger and G. Glawitsch, Monatsch. Chem, 88, 639 (1957).

3) L. Navias, "Fall Meeting of the Basic Science Division", The Amer. Cer. Soc., Detroit., Mich., Sept. 26 (1960).

4) R.E. Carter, J. Am. Ceram. Soc., 44, 116 (1961).

5) F.S. Stone and R.J.D. Tilley, "Reactivity of Solids" Proceedings of the 5 th international sym. posium on the reactivity of solids, edited by G. M. Schwab, (Pub. 1965) Elsevier, p. 583.

6) G. Yamaguchi and T. Tokuda, Bull. Chem. Soc. Japan, 40, 843 (1967).

7) E. Koch and C. Wagner, Z. physik. Chem., 34, 317 (1936).

8) I.S. Kainarskii and E.V Detyareva, Zh. Prikl. Khim., 36, 225 (1963).

9) M.I. Diesperova and V.A. Bron, Tr. Vost. Inst. Oguneuporov, No. 4, 164 (1963).

10) H. Yanagida and M. Atsumi, Yogyo-Kyokai-Shi, 75, 349 (1967).

11) S. Shimada, R. Furuichi and T. Ishii, Bull. Chem. Soc. Japan, 47, 2026 (1974).

12) S. Shimada, R. Furuichi and T. Ishii, Bull. Chem. Soc. Japan, 47, 2031 (1974).

13) I. Nitta "X-ray Crystallography", Maruzen, Tokyo, (1959), p. 406.

14) $Y$, Ichikawa, T. Murase, $Y$. Nurishi and $T$. Hibino, Nippon Kagaku Zasshi, 92, 843 (1971).

15) Y. Hayashi, Y. Inoue, Y. Nurishi and T. Hibino, ibid., 92, 1119 (1971).

16) M. Igeta, K. Azuma, Y. Nurishi and T. Hibino, ibid., 921126 (1971).

17) S. Yamamoto, K. Yoshimura, Y. Nurishi and T. Hibino, Nippon Kagaku Kaishi, 1972, 556.

18) J.O. Edwards, "Inorganic Reaction Mechanisms" Japanese edition translated by S. Kawaguchi, Kagaku Dojin, Kyoto (1965), p. 37.

19) O. Kubaschewski, "Metallurgical Thermochemistry" 4 th edition, Pergamon Press, (1967).

[Received December 2, 1974]

\title{
アルミン酸マグネシウムの生成過程に対する種々弗化物の作用機構
}

\author{
宮本雅文・橋場 稔・塗師幸夫・日比野泰三 \\ (岐阜大学 工学部 工業化学教室)
}

酸化アルミニウムと炭酸マグネシウムからアルミン酸 マグネシウムを生成する反応の初期段階での種々弗化物 添加の影響を研究した.アルカリ金属の弗化物を添加す ると $\mathrm{LiF}>\mathrm{NaF}>\mathrm{KF}>\mathrm{RbF}>\mathrm{CsF}$ の順序にアルミン酸 マグネシウムの生成反応を促進する. またアルカリ土類 金属の弗化物を添加すると, $\mathrm{MgF}_{2}>\mathrm{CaF}_{2}<\mathrm{SrF}_{2}<\mathrm{BaF}_{2}$ の順に反応促進効果が認められた. これらの反応過程で 弗素は酸化アルミニウムのみならす酸化マグネシウムに も同時に作用し，アルミン酸マグネシウムの生成は弗化 物と酸化アルミニウム, 酸化マグネシウムの三成分が同 時に相互作用する状態をへて生成すると推定した.この 結果にもとづいて，三成分の相互作用状態を活性化状態 として含むアルミン酸マグネシウムの生成機構としてつ ぎのような反応機構を提出した.

$$
\begin{aligned}
& \mathrm{MgO}+\mathrm{Al}_{2} \mathrm{O}_{3}+2 \mathrm{MF}\left(\mathrm{M}^{\prime} \mathrm{F}_{2}\right) \\
&=\left(\begin{array}{c}
\mathrm{Al}_{2}-\mathrm{O}_{3} \\
\mathrm{\uparrow} \\
\mathrm{F}-\mathrm{M} \\
\downarrow \\
\mathrm{Mg}-\mathrm{O}
\end{array}\right)=\mathrm{MgF}_{2}+\mathrm{M}_{2} \mathrm{Al}_{2} \mathrm{O}_{4}\left(\mathrm{M}^{\prime} \mathrm{Al}_{2} \mathrm{O}_{4}\right) \\
& \| \\
& \mathrm{MgAl}_{2} \mathrm{O}_{4}+2 \mathrm{MF}\left(\mathrm{M}^{\prime} \mathrm{F}_{2}\right)
\end{aligned}
$$

その結果, 反応 $\mathrm{MgO}+\mathrm{Al}_{2} \mathrm{O}_{3}+2 \mathrm{MF}\left(\mathrm{M}^{\prime} \mathrm{F}_{2}\right)=\mathrm{MgF}_{2}$ $+\mathrm{M}_{2} \mathrm{Al}_{2} \mathrm{O}_{4}\left(\mathrm{M}^{\prime} \mathrm{Al}_{2} \mathrm{O}_{4}\right)$ のエンタルピー変化を添加剤弗 化物の反応促進效果の目やすとして用いることができ， エンタルピー変化の小さいものほど促進効果が大きい. これによりアルカリ，アルカリ土類金属弗化物による促 進効果の順序を説明できる. 最後にコバルト, ニッケ ル，亜鉛の弗化物添加の影響について議論した.

(12/2/1974 受付) 